\title{
Apakah Pembelajaran Menggunakan Teknologi dapat Meningkatkan Literasi Manusia pada Generasi Z di Indonesia?
}

\author{
Lasti Yossi Hastini ${ }^{1}$, Rahmi Fahmi ${ }^{2}$, Hendra Lukito ${ }^{3}$ \\ ${ }^{1}$ Mahasiswa Program Doktor Ilmu Manajemen Unand, Padang, Indonesia \\ ${ }^{2,3}$ Program Studi Manajemen, FE Unand, Padang, Indonesia \\ Email: lastiyossi@gmail.com
}

\begin{abstract}
Abstrak
Saat ini telah diterapkan pembelajaran dengan menggunakan teknologi seperti e-learning, online-learning ataupun blended learning. Untuk menghadapi Revolusi Industi 4.0 Indonesia berusaha meningkatkan tiga literasi, yaitu literasi teknologi untuk memahami cara kerja mesin, aplikasi teknologi (Coding/Programming, Artificial Intelligence, \& Engineering Principles), literasi data untuk membaca, menganalisis, dan menggunakan informasi (Big Data) di dunia digital dan literasi manusia untuk kemampuan komunikasi, kolaborasi, berpikir kritis, kreatif dan inovatif serta memiliki keterampilan kepemimpinan, team work dan sebagainya. Pemerintah meluncurkan SPADA Indonesia untuk meningkatkan akses pendidikan tinggi yang bermutu di Indonesia. Generasi $Z$ adalah generasi yang saat ini berada di perguruan tinggi, otomatis mereka jadi sasaran utama dalam pelaksanaan SPADA dan peningkatan ketiga literasi tersebut. Generasi $Z$ memiliki karakteristik yang berbeda dengan generasi-generasi lain. Penelitian literature review ini bertujuan untuk mengetahui apakah penerapan pembelajaran dengan menggunakan teknologi dapat meningkatkan atau justru melemahkan kemampuan literasi manusia pada Generasi Z di Indonesia. Metode yang digunakan adalah literature review. Hasilnya menunjukkan bahwa penggunaan teknologi dalam pembelajaran masih sulit untuk dapat meningkatkan literasi manusia pada Generasi $Z$ karena mereka cenderung sulit berkomunikasi secara langsung, instan dan memudarkan nilai-nilai budaya dan agama.
\end{abstract}

Kata kunci: Generasi Z, Literasi manusia, e-learning, blended learning dan online-learning

\section{Abstract}

Learning methods using technology such as e-learning, online-learning or blended learning have begun to be applied. In the context of facing the 4.0 Indonesian Revolution, Indonesia is trying to improve three new literacies, namely technology literacy to understand the workings of machines, technology applications (Coding / Programming, Artificial Intelligence \& Engineering Principles), data literacy for reading, analyzing, and using information (Big Data) in the digital world and human literacy for communication skills, collaboration, critical thinking, creative and innovative as well as having leadership skills, team work and so on. The Ministry of Higher Education (Dikti) also launched the Indonesian Online Learning System (SPADA) to improve access to quality higher education in Indonesia. Generation $Z$ is the generation currently in tertiary education, so they automatically become the main target in the implementation of SPADA and the increase in the three literacies. Generation $Z$ has certain characteristics that are different from other generations. This literature review research aims to find out whether the application of learning by using technology can increase or even lower human literacy in Generation $Z$ in Indonesia. The method used in this research is literature review. The results show that the use of technology in learning is still difficult to be able to increase human literacy in Generation $Z$ 
because they tend to have difficulty communicating directly, instantly and fading cultural and religious values.

Keywords: Generation Z, human literacy, e-learning, and blended learning

\section{Pendahuluan}

Generasi $\mathrm{Z}$ adalah generasi yang dari lahir berinteraksi dengan kemajuan teknologi. Pengasuhan mereka bahkan banyak dibantu oleh teknologi dan internet. Terlahir antara tahun 1995 sampai 2012, mereka tidak sempat merasakan kehidupan tanpa teknologi dan internet. Keberadaan teknologi dan internet menjadi elemen penting dari kehidupan dan keseharian mereka. Bagi Generasi Z teknologi dan internet merupakan sesuatu hal yang harus ada, bukan merupakan sebuah inovasi seperti pandangan generasi lainnya.

Kemajuan teknologi dan pesatnya arus informasi melalui internet telah mempengaruhi kehidupan Generasi Z. Mereka terbiasa berkomunikasi dengan menggunakan gadget yang mereka miliki, melihat informasi tentang berbagai hal dari dunia luar melalui internet, bermain game dan bahkan berbelanja melalui satu benda yang ada di dalam genggaman mereka yaitu smartphone (gadget). Hampir semua Generasi Z memiliki smartphone ini baik yang kaya ataupun termasuk yang termasuk kategori miskin, yang tinggal di perkotaan maupun di perdesaan. Bisa dikatakan semua Generasi Z terpapar penggunaan smartphone setiap harinya. Tingkat ketergantungan Generasi Z terhadap smartphone lebih tinggi dibandingkan terhadap televisi. Mereka akan lebih kesal bila tidak dapat mengakses internet dibandingkan kehilangan uang jajan [1].

Generasi Z sangat akrab dengan media sosial. Hasil penelitian Palley 2012 dalam Turner (2015) memperlihatkan bahwa 60\% responden Generasi Z memulai kehidupan sosial mereka secara online, $50 \%$ Generasi $\mathrm{Z}$ lebih menyukai berkomunikasi secara online daripada berbicara langsung dikehidupan nyata, bahkan $70 \%$ Generasi $\mathrm{Z}$ lebih nyaman berkomunikasi dengan temannya secara online. [1]

Mengingat bagaimana Generasi $\mathrm{Z}$ dalam penggunaan teknologi dan internet dalam kesehariannya membuat mereka terlatih untuk tertarik pada beberapa subjek atau masalah pada saat bersamaan. Kondisi ini kemungkinan disebabkan sinkronisasi keterampilan motorik yang dimiliki oleh Generasi $\mathrm{Z}$ yang cukup tinggi terutama pada mata, tangan dan telinga dibandingkan dengan generasi-generasi lain sebelum mereka.

Berkup (2014) menjelaskan beberapa ciri Generasi Z yang berkaitan dengan penggunaan teknologi. Beberapa ciri yang dimaksud adalah bersosialisasi melalui internet, mengkonsumsi internet dengan sangat cepat, dengan teknologi di tangan mereka cenderung efisien dan inovatif, menyukai permainan yang menantang kreativitas [2] .

Dalam penggunaan teknologi terutama smartphone, sebagian Generasi $\mathrm{Z}$ menggunakannya untuk pemberdayaan diri mereka selain juga untuk hiburan. Namun bertolak belakang kondisinya dengan sebagian dari generasi $\mathrm{Z}$ yang lain yang ternyata masih memiliki kesadaran literasi digital yang sangat rendah, sehingga mereka umumnya menggunakan smartphone hanya untuk kepentingan konsumtif saja [3]. Menurut Perrez dkk (2016) Generasi Z memiliki orientasi yang bagus untuk pendidikan terutama pembelajaran seumur hidup, memiliki kemampuan dan pengetahuan yang banyak terkait teknologi karena integrasi mereka yang tinggi pada internet [4].

Dalam satu hari Generasi Z menghabiskan waktunya sekitar 9 jam sehari untuk 
menggunakan smartphone mereka dan membuat mereka sangat tergantung pada teknologi seluler. Meskipun demikian Generasi Z ternyata kurang mampu untuk menganalisis validitas informasi yang ia peroleh ataupun memanfaatkan informasi yang diperoleh secara kritis. Rentang perhatian mereka sangat singkat sekitar 8 detik [5].

Mengingat bagaimana karakteristik Generasi $\mathrm{Z}$ sangat suka menggunakan gadgetnya, mulai dikembangkan metode pembelajaran yang dapat memenuhi kesukaan mereka. Saat ini sudah berkembang banyak metode pembelajaran dengan menggunakan teknologi yang lebih sering disebut e-learning, blended learning, ataupun online-learning. Meskipun demikian bukan berarti metode pembelajaran face to face tidak lagi digunakan untuk pembelajaran pada Generasi Z. Metode pembelajaran tatap muka masih dominan digunakan terutama di Indonesia.

Penelitian-penelitian berkaitan dengan pembelajaran dengan pemanfaatan teknologi ini juga semakin banyak dipublikasikan. Contohnya bagaimana pendekatan belajar untuk Generasi Z dikaitkan dengan e-learning [6], pendidikan di era revolusi industri [7], penggunaan teknologi dan karakteristik belajar [8], ataupun bagaimana pembelajaran Digital [3], [9]. Kementerian Riset dan Perguruan Tinggi juga mulai menggalakkan penggunaan e-learning ini. Bertepatan dengan peringatan hari Pendidikan Nasional tahun 2018, Menteri Riset, Teknologi dan Pendidikan Tinggi Prof. Muhammad Nasir meluncurkan e-learning/Hybrid learning melalui SPADA Indonesia. Peluncuran $e$ learning/Hybrid learning ini untuk menjamin kualitas pendidikan tinggi secara merata di Indonesia. Selain itu Menristek juga berharap semua civitas akademika dan masyarakat umum harus memiliki kemampuan literasi teknologi, literasi data dan literasi kemanusiaan. [10]. Literasi teknologi adalah kemampuan untuk memahami bagaimana cara kerja mesin, dan penggunaan aplikasi teknologi (Coding/Programming, Artificial Intelligence, \& Engineering Principles). Literasi data adalah kemampuan dalam memanfaatkan data berupa membaca, menganalisis, dan menggunakan informasi (Big Data) di dunia digital. Literasi manusia adalah kemampuan dalam berkomunikasi, melakukan kolaborasi, berpikir kritis, kreatif dan inovatif serta memiliki keterampilan kepemimpinan, team work dan sebagainya [11].

Dengan himbauan ini timbul pertanyaan bagaimana pembelajaran dengan menggunakan teknologi dapat meningkatkan ketiga literasi tersebut, terutama terkait dengan literasi manusia? Perlu diingat bahwa dengan penggunaan e-learning artinya Generasi $\mathrm{Z}$ akan semakin tergantung dengan teknologi terutama smartphonenya. Menurut Turner (2015) Generasi Z kurang mampu berkomunikasi secara tatap muka, dan cenderung menggunakan smartphone untuk menghindari situasi-situasi yang tidak mereka inginkan, sehingga keterampilan mereka untuk melakukan coping (mengatasi) situasi sulit akan sangat rendah bila semakin sering mereka dengan smartphonenya [1]. Menurut Steyer (2012 dalam Turner 2015) penggunaan teknologi yang sangat tinggi berpotensi mengganggu perkembangan neurologis. Saat seorang individu terlalu sering menggunakan mesin pencari yang dapat menemukan jawaban apapun yang dibutuhkan dalam hitungan detik akan mengubah pola konsentrasi, cara membaca dan merenungnya. Selain itu semakin terlihat bahwa Generasi Z kehilangan nilai-nilai atau norma-norma budaya dan agama. Contohnya semakin banyaknya komunitas LGBT tumbuh di dalam Generasi Z karena menunjukkan orientasi seksual bagi mereka merupakan hal yang biasa. [1]. Kondisi ini perlu menjadi pertimbangan bagi Pemerintah ataupun para Dosen dan Guru dalam memberikan materi dalam penggunaan e-learning yang terkait dengan literasi manusia. 
Tujuan dari penelitian ini adalah untuk mencoba menelaah bagaimana pembelajaran dengan menggunakan teknologi mampu meningkatkan literasi manusia pada Generasi Z . Literasi teknologi dan literasi data pelaksanaannya sangat terkait dengan kemampuan penggunaan teknologi, sehingga pembelajaran melalui e-learning, blended learning ataupun online-learning akan mempermudah peningkatan literasinya. Sementara itu literasi manusia berbeda dengan kedua literasi yang lain. Mungkinkah pembelajaran dengan teknologi dapat meningkatkan literasi manusia atau justru semakin melemahkan kemampuan dalam literasinya? Selama ini Generasi $Z$ sudah sangat terpapar dengan teknologi, kemampuan untuk fokus mereka sangat singkat dan nilai-nilai yang mereka pegang sat ini sangat universal yang menyebabkan identitas budaya dan agama menjadi semakin hilang pada diri mereka. Apakah memang kondisi seperti ini yang kita inginkan untuk Generasi Z? Bagaimana mungkin kita dapat membiarkan mereka semakin terpapar teknologi dengan memperbanyak e-learning atau online-learning untuk pelajaran-pelajaran yang terkait dengan kemampuan literasi manusia? Cocokkah penggunaan teknologi yang terlalu banyak dengan tujuan pendidikan dan pembelajaran pada Negara Indonesia? Bukankah seharusnya untuk meningkatkan literasi manusia Generasi Z harus diajarkan kemampuan komunikasi secara langsung, kemampuan pengambilan keputusan, kepemimpinan dalam dunia nyata, bukan hanya dalam dunia maya. Penelitian ini menjadi penting untuk mengemukakan kemungkinan hasil yang diperoleh dalam pembelajaran yang menggunakan teknologi dalam upaya peningkatan literasi manusia.

\subsection{Generasi Z}

\section{Kajian Pustaka}

Berdasarkan pembagian tahun kelahiran Generasi $\mathrm{Z}$ adalah mereka yang lahir antara tahun 1995 sampai rahun 2010. Zemke dan kawan-kawan (1999) mencoba membedakan Generasi Z ini dengan generasi-generasi lain berdasarkan tahun kelahirannya. Mereka membagi atas 5 generasi yaitu generasi veteran yang lahir tahun 1925 sampai 1946, generasi baby boomer yang lahir tahun 1946 sampai 1960, geberasi X yang lahir tahun 1960 sampai 1980, generasi Y yang lahir tahun 1980 sampai 1995 dan generasi Z yang lahir tahun 1995 sampai 2010 [12].

Selain pembedaan tentang tahun kelahiran juga terdapat perbedaan karakter antara Generasi Z dengan generasi-generasi sebelumnya. Bencsik (2016) mencoba menjelaskan perbedaan Generasi Z dengan generasi-generasi lainnya.

Dari segi sudut padang dalam melihat segala sesuatu, Generasi Z cenderung tidak memiliki rasa komitmen, bahagia dengan apa yang ia miliki saat ini dan hidup untuk saat ini. Berbeda dengan Generasi Baby Boomer yang cenderung berpikir secara terpadu dan komunal, Generasi X yang cenderung memiliki cara pandang berpusat pada diri sendiri dan untuk kepentingan jangka menengah, sedangkan Generasi $\mathrm{Y}$ atau milenial cenderung lebih egoistic dan untuk kepentingan jangka pendek. [13].

Dari segi penggunaan IT, Generasi Z menggunakannya secara intutitif karena mereka memang dari lahir terbiasa dengan IT. Sementara itu Generasi Baby Boomer adalah generasi yang sangat tergantung pada instruksi dirinya dan dalam menggunakan teknologi tidak secara lengkap artinya hanya teknologi atau bagian tertentu saja yang digunakan itupun pada saat-saat tertentu saja. Sebagian besar mereka justru sulit menginstruksikan dirinya untuk berinteraksi dengan penggunaan IT, sebagian lain masih bersedia mencoba namun tetap kurang mampu memahami secara lengkap. Dibandingkan Generasi Baby 
Boomer, Generasi X lebih percaya diri dalam penggunaan IT, sedangkan Generasi Y telah menggunakan IT dalam kehidupan sehari-harinya. [13].

Tentang nilai-nilai yang dianut, Generasi $\mathrm{Z}$ memiliki reaksi yang cepat terhadap apa pun, hidup untuk saat ini, kurang berpikir panjang, mencari kesenangan sehingga terjadi tumpang tindih batas antara pekerjaan dan hiburan, terbaginya perhatian, tidak ada keinginan untuk memehami sesuatu, kurang berpikir konsekuen. Sangat berbeda dengan Generasi Baby Boomer yang sabar, memiliki EQ yang tinggi, lebih menghargai tradisi, pekerja keras, namun cenderung pasif, sinis dan tidak fleksibel. Generasi X lebih terbuka dan menghargai perbedaan, pekerja keras, praktis, adil, taat aturan namun materialistis dan ingin membuktikan kemampuan diri. Nilai yang dianut Generasi Y menuntut kebebasan informasi, fleksibel, mobilitas tinggi, kreatif, mandiri, senang mencari bentuk-bentuk pengetahuan baru sehingga pengetahuannya luas namun dangkal, tidak menghormati tradisi, EQ dan soft skill rendah, arogan, senang pekerjaan rumahan dan paruh waktu, [13].

Hasil penelitian yang dilakukan oleh Lembaga Riset The Haris Poll (2018) di New York pada Generasi Z dan Generasi Y sebanyak 2587 responden representatif memperlihatkan penggunaan online rata-rata dalam seminggu yang dilakukan oleh Generasi $\mathrm{Z}$ dan Generasi Y. Umumnya mereka mengunjungi situs web yang berbagi video, menonton video online dan bermain game online. Generasi $\mathrm{Z}$ cenderung lebih memilih Youtube atau aplikasi lain untuk belajar sementara Generasi Y lebih suka buku yang dicetak untuk belajar. Meskipun demikian baik Generasi Z dan Generasi Y sama-sama menganggap guru atau dosen adalah bagian penting dalam pembelajaran dan pengembangan diri, serta menyukai aktivitas berinteraksi langsung dengan teman-teman sekelas sebagai pengalaman pembelajaran. Ketika menemukan masalah berkaitan pembelajaran, maka baik Generasi Z maupun Generasi Y lebih memilih mencari tahu sendiri melalui internet, buku atau teman daripada bertanya dengan guru [14].

Generasi $\mathrm{Z}$ terpapar media melalui internet sangat lama melebihi aktivitas lain selain tidur. Bahkan dari sisi demografi aktifnya penggunaan media melalui internet ini melanda mereka yang tinggal diperkotaan dan pedesaan, tidak hanya dialami oleh yang kaya saja, tetapi juga melanda mereka yang kondisi perekonomian lemah [15]. Menurut Palley (2012 dalam Turner, 2015) 50\% Generasi Z lebih nyaman berkomunikasi secara online daripada langsung, bahkan saat berbicara dengan teman pun 70\% Generasi Z lebih suka secara online daripada berkomunikasi langsung [1].

Ketergantungan Generasi Z kepada mesin pencari sangat tinggi, namun mereka kurang dapat mengkritisi validasi informasi yang mereka peroleh. Kecenderungan mereka mudah puas (kepuasan instan). Dalam belajar Generasi Z lebih suka memperhatikan dan berlatih, bukan dengan cara membaca atau mendengarkan ceramah. Oleh sebab itu, Generasi $\mathrm{Z}$ membutuhkan metode pembelajaran yang berbeda dengan generasi-generasi sebelumnya. [5]

Menurut Mosca dan kawan-kawan (2019), Generasi Z memiliki rentang perhatian yang pendek. Mereka lebih mudah memahami gambar visual. Oleh sebab itu, bagi Generasi $\mathrm{Z}$ pembelajaran yang tepat adalah yang menggunakan gambar, animasi ataupun video. [6]

\subsection{Learning}

Learning (belajar) adalah upaya manusia untuk memperoleh pengetahuan maupun keterampilan, dengan menghasilkan perubahan jangka panjang. [6]. Ciri-ciri telah terjadinya pembelajaran adalah (a) tercapainya perilaku baru; (b) mampu mengingat 
informasi, fakta, dan pengetahuan, lebih cepat dari sebelumnya; (c) Mampu melihat dan mendiskusikan suatu topik dengan lebih detail [16].

Awalnya orang lebih mengenal proses pembelajaran yang dilakukan secara tatap muka (face to face-learning). Pembelajaran face to face adalah pembelajaran yang dilakukan dengan proses interaksi langsung antara intruktur (pengajar) dengan peserta atau siswa. Umumnya pembelajaran dilakukan dengan metode ceramah, tanya jawab, diskusi, demonstrasi, eksperimen dan lain sebagainya.

Saat ini berkembang empat kuadran setting belajar yaitu sinkron langsung, sinkron maya, asinkron mandiri dan asinkron kolaboratif. seperti pada gambar 2.1 berikut. Setting belajar secara sinkron berbeda dengan asinkron. Menurut Riva (2002) dalam O'Byrne (2015) pembelajaran secara sinkron merupakan pembelajaran dengan komunikasi real time seperti pada percakapan ataupun diskusi. [17]. Contoh langsung secara sinkron adalah face to face-learning, sedangkan tidak langsung (offline) secara sinkron contohnya adalah pembelajaran dengan webinar. Sementara pembelajaran secara asinkron mengacu pada pembelajaran dengan komunikasi di luar real time, sehingga biasanya menggunakan teks, video, atau obrolan audio. Teks dan alat digital yang mendorong pembelajaran asinkron meliputi video, papan buletin, bacaan, dan aktivitas menulis atau blog [17].

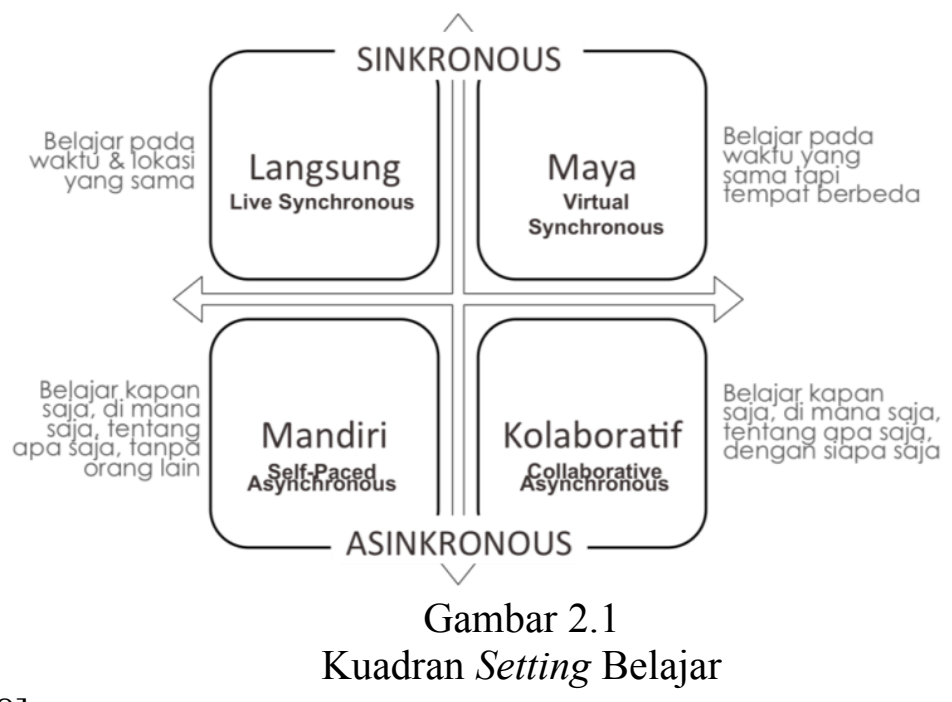

Sumber: [18]

\subsection{Distance-learning}

Distance-learning atau pembelajaran jarak jauh adalah pembelajaran yang dilakukan antara instruktur dan peserta yang berada pada lokasi berbeda. Distance-learning ini telah dimulai sejak awal abad ke 18. Bentuk distance-learning pertama kali adalah dengan pengiriman bahan pembelajaran berbasis kertas melalui pos, kemudian siswa mengirimkan tugasnya juga melalui pos untuk bahan evaluasi pembelajarannya. Kondisi ini menyebabkan komunikasi yang lambat dan tidak memungkinkan terjadinya interaksi antar instruktur dan peserta [19].

Saat ini pelaksanaan distance-learning semakin maju dengan menggunakan teknologi komputasi digital. Penggunaan teknologi ini membuat jarak tempuh pelaksanaan distance-learning bisa lebih jauh dan tersebar di mana-mana. Dengan menggunakan email, sumberdaya berbasis web ataupun diskusi online pelaksanaan distance-learning menjadi 
lebih interaktif dan dapat membantu banyak peserta atau siswa yang terlibat dalam proses pembelajaran menjadi lebih memahami materinya [19].

\subsection{E-learning, Online-learning, Blended (Hybrid) Learning}

Terdapat berbagai definisi terkait e-learning. Sebagian penulis dalam artikel membahas e-learning sebagai pembelajaran yang diakses melalui teknologi yang berbasis web. Penulis artikel yang lain menyebutkan bahwa konten dan metode pengajaran dalam e-learning bukan hanya melalui CD Room, internet atau intranet, tetapi juga melalui audio, rekaman video, siaran satelit, dan TV interaktif [20].

Tavangarian dkk (2004) menjelaskan e-learning sebagai bentuk pembelajaran dan pengajaran yang didukung elektonik secara procedural dengan tujuan untuk mempengaruhi konstruksi pengetahuan, dilakukan berdasarkan pengetahuan dasar yang telah dimiliki peserta, pengalaman serta praktek di lapangan. Dengan demikian interaksi dan komunikasi dapat dilakukan secara langsung ataupun melalui jaringan dengan menggunakan teknologi. [21]. Definisi ini penulis anggap paling tepat karena dapat membedakan dengan lebih jelas antara e-learning dengan online-learning.

E-learning mempunyai 3 fungsi yaitu (a) suplemen atau tambahan. Karena bersifat tambahan pelajar tidak harus mengakses materi pembelajaran yang bersifat elektronik, namun dengan mengaksesnya peserta akan mendapatkan tambahan pengetahuan dan wawasan; (b) komplemen atau pelengkap. Materi e-learning ditujukan untuk melengkapi atau materi pengayaan bagi peserta yang mengikuti pembelajaran secara tradisional (face to face); (c) substitusi atau pengganti. E-learning menggantikan kelas face to face, dengan demikian pelajar dapat mengatur secara mandiri kegiatan pembelajaran dan menyesuaikan waktunya dengan aktivitas-aktivitas lain [22].

Dalam prakteknya e-learning merupakan kontinum yang memiliki tiga kategori seperti gambar 2.2.

\begin{tabular}{|c|c|c|}
\hline Adjunct & Mixed/Blended & Fully Online \\
\hline $\begin{array}{l}\text { Continuing tradisional } \\
\text { learning procceses, but } \\
\text { enhancing them or } \\
\text { extending them beyond } \\
\text { classroom hour with } \\
\text { daring resources } \\
\text { particularly using } \\
\text { computer mediated } \\
\text { communication (CMC). }\end{array}$ & $\begin{array}{l}\text { Becoming as integral } \\
\text { part of curricula. Mixing } \\
\text { delivery of content, } \\
\text { CMC, or daring } \\
\text { collaboration with face } \\
\text { to face session. } \\
\text { Determining the } \\
\text { appropriateness of } \\
\text { daring or face to face to } \\
\text { deliver different aspects } \\
\text { of curricula. }\end{array}$ & $\begin{array}{l}\text { All elarning interactiosn } \\
\text { takes place daring and } \\
\text { all learning materials } \\
\text { delivered daring, e.g. } \\
\text { CMS, streaming video, } \\
\text { audio hyperlinked course } \\
\text { materials, text and } \\
\text { images.daring } \\
\text { collaboration is the key } \\
\text { features of this model. }\end{array}$ \\
\hline
\end{tabular}

Gambar 2.2

Sumber [18]

Kontinum E-Learning

Keterangan:

a. Adjuct adalah pembelajaran face to face ditambah dengan materi penunjang yang bisa dicari melalui internet atau menggunakan bantuan komputer, LCD proyektor atau multimedia lainnya di dalam kelas;

b. Mixed/Blended adalah menggunakan system pembelajaran daring (jarak jauh) sebagai bagian yang tidak terpisahkan dari pembelajaran face to face;

c. Fully daring adalah proses pembelajaran dan interaksi sepenuhnya dalam bentuk daring (jarak jauh) tanpa menggunakan face to face sama sekali. 
Online-learning adalah bagian dari pembelajaran jarak jauh yang memanfaatkan teknologi untuk memediasi proses pembelajaran. Pembelajaran sepenuhnya disampaikan melalui teknologi internet. Baik peserta maupun instruktur tidak perlu mengakses bahan pembelajaran pada waktu yang bersamaan. Saat ini online-learning sering berbasis komputer ataupun berbasis web. [19].

Dengan memperhatikan definisi di atas bisa disimpulkan online-learning adalah generasi terbaru dari distance-learning. Selain itu online-learning juga bagian dari $e$ learning karena juga menggunakan teknologi elektronik.

Berdasarkan kontinum e-learning yang telah dijelaskan pada sub bab sebelumnya dapat dikatakan bahwa blended learning merupakan perpaduan pelaksanaan face to face dengan online-learning. Selain menggunakan istilah blended learning sering juga menggunakan istilah hybrid learning atau mixed mode.

Blended learning bukan berarti memasukkan teknologi pada pembelajaran face to face, namun merupakan upaya mendesain ulang proses pembelajaran dikembangkan dan dijadwalkan secara jelas melalui instruksi langsung dan visual. Interaksi yang diciptakan melalui blended learning lebih instensif baik antara peserta dengan instruktur, antar sesame peserta ataupun antar peserta dengan konten pembelajarannya [23]. Blended learning menggabungkan metode pembelajaran sinkron dengan asinkron.

\subsection{Penerapan E-learning di Beberapa Negara}

Berdasarkan penelitian Mc Conneli (2018) digambarkan bahwa minat terhadap $e$ learning ataupun pembelajaran online di Cina semakin meningkat. Namun metode ceramah masih menjadi sistem pendidikan utama di Cina. Pergeseran menuju penerapan $e$ learning mulai terlihat, tetapi hanya sebagian kecil dosen-dosen yang antusias untuk menerapkannya. Tradisi pendidikan yang bersifat konservatif dalam pendidikan di Cina menunjukkan pergeseran e-learning untuk menjadi system pendidikan yang utama masih sangat jauh untuk dapat terjadi. Point-point utama dari hasil temuannya adalah sebagai berikut: (a) Hampir setiap guru lebih menyukai metode tatap muka 2-3 jam, karena menurut mereka penguasaan materi teoritis tidak dapat dicapai secara online, sehingga tidak ada yang menganggap e-learning atau pembelajaran online sebagai metode pengajaran yang utama; (b) penggabungan metode kolaboratif secara online dalam strategi e-learning dinilai efektif meningkatkan gairah belajar mahasiswa. Namun partisipasi online mahasiswa secara penuh justru dinilai kurang bagus karena mahasiswa cenderung kurang memiliki inisiatif; (c) Network learning dimana materi dalam bentuk e-teks ditempatkan secara online dan siswa mempelajarinya secara mandiri dengan sedikit interaksi dengan dosen atau teman. Network learning ini dianggap metode e-learning yang paling umum di Cina namun memiliki kualitas yang kurang tinggi; (d) kemandirian mahasiswa dalam pelaksanaan pembelajaran mandiri seperti metode e-learning tidak merata, tergantung latar belakang mahasiswanya. Sebagian besar dari mereka terbiasa mengharapkan dosen mengajarkan mereka secara lengkap; (e) Kuliah tatap muka dilanjutkan dengan pemberian tugas online dianggap sebagai metode e-learning yang paling mungkin diterapkan di Cina; (f) pengadaan infrastruktur untuk e-learning terutama pada kelembagaan lokal masih sangat tergantung pada sumber daya dan konteks sosial juga politik pada masing-masing lembaga; (g) Masih banyak dosen yang membutuhkan akses peluang pengembangan profesional untuk membantu mereka menjalankan transisi dari pembelajaran tatap muka secara penuh menuju penggabungan pembelajaran secara online [24]. 
Di Malaysia penggunaan e-learning berkembang secara pesat ditandai dengan tingkat penerimaan yang tinggi pada penggunanya atau mahasiswa [25], [26]. Pada Universiti Teknologi Malaysia diketahui bahwa self efficacy, serta konten yang ada pada $e$ learning mempengaruhi kepuasan dan manfaat yang dirasakan mahasiswa terhadap $e$ learning. Kondisi ini mempengaruhi niat mahasiswa dalam penggunaan e-learning untuk selanjutnya [25]. Sementara itu pada Lembaga Pendidikan Guru di Malaysia diketahui faktor-faktor yang mempengaruhi penerimaan mahasiswa terhadap penggunaan e-learning yaitu: (a) mahasiswa percaya bahwa dengan menggunakan e-learning dapat meningkatkan pemahaman dan efektivitas pembelajaran. E-learning dinilai bermanfaat dan mudah digunakan; (b) mahasiswa merasa e-learning mampu memberikan informasi yang akurat, baik, detail dan tepat waktu; (c) faktor dosen seperti keramahan dosen, motivasi yang diberikan dosen dalam penggunaan e-learning dan sebagainya mempengaruhi penerimaan mahasiswa dalam menggunakan e-learning; (d) kualitas system mempengaruhi penerimaan mahasiswa terhadap e-learning namun mahasiswa tetap lebih menyukai pendekatan tatap muka untuk membantu proses pembelajarannya; (e) dukungan teknis dari institusi seperti penyediaan fasilitas dan pelatihan sangat mempengaruhi penerimaan mahasiswa; (f) kualitas informasi seperti kemudahan mencari informasi, struktur komponen e-learning mudah dipahami dan sebagai membuat mahasiswa mau menerima penggunaan e-learning [26].

Kawasan Timur Tengah, merupakan kawasan yang termasuk terlambat dalam mengadopsi e-learning karena terlambat juga dalam penggunaan internet. Kondisi ini tentunya berdampak pada pelaksanaan e-learning pada saat tersebut. Uni Emerat Arab adalah negara yang termasuk paling awal memberikan akses internet kepada warga negaranya. [27]. Meskipun demikian saat ini terjadi kemajuan pesat dalam penggunaan $e$ learning ini. Salah satu penelitian terkait penggunaan e-learning dilaksanakan di Kuwait oleh Al-Hunnaiyan dan kawan-kawan tahun 2018. Penelitian ini lebih fokus pada persepsi mahasiswa dan instruktur terhadap penggunaan mobile-learning. Hasilnya memperlihatkan persepsi yang positif terhadap penggunaan mobile-learning. Baik mahasiswa maupun instruktur menilai mobile-learning adalah metode pembelajaran yang menarik karena dapat dilaksanakan secara bebas dimana saja dan kapan saja. Aplikasi media sosial yang paling cocok digunakan oleh instruktur untuk pembelajaran kolaboratif adalah media sosial yang menggunakan video seperti youtube dan snapchat yang keduanya juga sering digunakan oleh mahasiswa. Namun penggunaan media sosial akan sedikit terhambat ketika dikaitkan dengan norma budaya dan agama, seperti adanya pemisahan gender. Selain itu yang dapat menjadi hambatan adalah karena ketika mobile-learning diterapkan akan membuat beban kerja instruktur bertambah untuk mempersiapkan pembelajarannya [28]. Sementara itu untuk Uni Emerat Arab diketahui bahwa faktor-faktor yang mendukung penerimaan terhadap penggunaan e-learning adalah adanya kesempatan berbagi pengetahuan dan kualitas system. Kesempatan berbagi pengetahuan menjadi hal yang sangat penting bagi mahasiswa di Perguruan Tinggi karena banyaknya data dan informasi yang dibutuhkan. Kualitas system juga sangat mempengaruhi penerimaan mahasiswa terhadap e-learning karena aksesibilitas, kegunaan, keandalan dan stabilitas akan berperan besar membuat pengguna dalam hal ini mahasiswa antusian dalam menggunakan e-learning. [29].

\subsection{Penggunaan E-Learning di Indonesia}

Saat ini penggunaan e-learning di Indonesia didukung langsung oleh Direktorat Jenderal Pembelajaran dan Kemahasiswaan (BELMAWA) Kementrian Riset, Teknologi, 
dan Pendidikan Tinggi (KEMENRISTEKDIKTI). Dukungan ini bertujuan agar penyelenggaraan pendidikan jarak jauh semakin mudah dan meratanya pendidikan tinggi yang berkualitas [30], [31]. Pendidikan Jarak Jauh atau PJJ merupakan pendidikan dimana lokasi peserta didiknya berbeda dengan lokasi pendidik, dan proses pembelajarannya menggunakan teknologi informasi dan komunikasi, serta media lainnya [30].

Sebelumnya e-learning ini juga sudah dilakukan oleh Universitas Terbuka Indonesia melalui kuliah jarak jauhnya. E-learning untuk Perguruan Tinggi di Indonesia, penerapannya dalam bentuk Pendidikan Jarak Jauh. Menurut aturan Menristekdikti, Pendidikan Jarak Jauh dapat dilakukan dalam tiga bentuk yaitu (a) mata kuliah; (b) program studi dan (c) perguruan tinggi. [32].

Sejak 15 Oktober 2014 Direktorat Pembelajaran dan Kemahasiswaan (Belmawa), Direktorat Pendidikan Tinggi telah mengembangkan program Pembelajaran Daring Indonesia Terbuka dan Terpadu (PDITT). PDITT Kemudian berubah menjadi Sistem Pembelajaran Daring (SPADA) pada 18 September 2018. Baik PDITT maupun SPADA dimaksudkan untuk mendukung penerapan Massive Open Online Course (MOOCs) di Indonesia. Dengan adanya SPADA ini diharapkan akses Pendidikan tinggi yang bermutu semakin meningkat, yang dilaksanakan dengan menggunakan teknologi informasi dan komunikasi sebagai wahana alih kredit, program pendidikan (degree program), pengembangan profesi berkelanjutan dan belajar sepanjang hayat bagi seluruh masyarakat Indonesia [18].

Terdapat tiga program dalam SPADA Indonesia yaitu (a) materi terbuka, menyediakan materi mata kuliah tertentu yang disajikan secara online pada berbagai bentuk media yang dapat diakses oleh mahasiswa ataupun dosen kapan saja dan di mana saja; (b) mata kuliah terbuka, merupakan sistem pembelajaran daring satu matakuliah utuh yang dapat digunakan oleh dosen terkait sebagai mata kuliah daring untuk diselenggarakan dalam pembelajaran; (c) mata kuliah Daring, merupakan matakuliah dalam bentuk pembelajaran Daring secara keseluruhan, oleh salah satu Perguruan Tinggi penyelenggara kepada Perguruan Tinggi Mitra sebagai sarana alih kredit dan nilai yang diperoleh mahasiswa ditransfer dari Perguruan Tinggi penyelenggara pada Perguruan Tinggi di mana mereka terdaftar [33].

Pada penyelenggaraan pertama pembelajaran Daring di Indonesia mulai Oktober 2014 sampai januari 2015 dilaksanakan oleh 5 Perguruan Tinggi dengan 14 mata kuliah Daring, dengan peserta sebanyak 658 mahasiswa. Penyelenggaraan kedua pada Bulan September sampai Desember 2015 oleh 5 Perguruan Tinggi, dengan 17 mata kuliah Daring yang baru dan 1088 mahasiswa sebagai peserta. [18].

Setelah beberapa kali menyelenggarakan Daring, ditemukan beberapa kelemahan dalam pelaksanaannya, yaitu (a) media pembelajaran yang digunakan masih monoton, umumnya berbentuk teks dan visual, pemanfaatan multimedia ataupun hypermedia belum ada; (b) alur pembelajaran masih sebatas mengarahkan mahasiswa untuk membaca dari melakukan pembelajaran mandiri, sehingga alurnya cenderung monoton; (c) masih kebingungan menentukan teknologi pembelajaran sinkron dan asinkron, evaluasi pembelajaran juga masih monoton berbentuk objektif. [18].

\subsection{Contoh Penerapan E-Learning Literasi Manusia}

Sangat sedikit makalah yang membahas penerapan e-learning untuk peningkatan literasi manusia. Salah satu contoh penerapan e-learning untuk literasi manusia dibahas dalam tulisan McFarlane dkk (2003) menyatakan tidak ada satupun program e-learning 
untuk kepemimpinan yang dapat menjamin keberhasilan secara total. Keberhasilan suatu program sangat tergantung budaya dan sulit untuk digeneralisasi. Program-program terkait kepemimpinan melibatkan elemen kognitif dan afektif, dimana elemen kognitif dapat dipenuhi melalui e-learning ataupun blended learning, namun elemen afektif mungkin akan sulit dilakukan dengan metode online karena menyangkut keterampilan interpersonal [34].

\section{Pembahasan}

Pembelajaran dengan menggunakan teknologi informasi dan komunikasi telah berkembang pesat baik di dunia maupun di Indonesia. Pengembangan metode pembelajaran ini tidak terlepas dari tuntutan revolusi industri 4.0. Harapannya penggunaan teknologi dalam pembelajaran baik itu berupa e-learning, online-learning ataupun blended learning dapat memberikan hasil yang maksimal pada Generasi $\mathrm{Z}$ termasuk untuk meningkatkan literasi teknologi, data, dan manusia.

\subsection{Penerimaan Penggunaan Teknologi dalam Pembelajaran}

Penerimaan mahasiswa yang merupakan Generasi Z terhadap penggunaan teknologi dalam pembelajaran, seperti e-learning, termasuk digital learning ataupun mobile-learning cukup tinggi. Di Malaysia mereka menganggap penggunaan e-learning sangat bermanfaat, sehingga berniat untuk tetap menggunakannya [25], [26]. Sementara itu di Kuwait penggunaan mobile-learning dianggap para mahasiswa dan dosen sebagai pengalaman yang menarik [28]. Di Uni Emerat Arab penggunaan e-learning menjadi sangat menarik karena mahasiswa merasa kemudahan dalam mencari informasi yang dibutuhkannya [29]. Hal yang sama juga terjadi di Cina, minat terhadap penggunaan e-learning semakin meningkat, meskipun face to face-learning tetap menjadi metode pembelajaran utama [24].

Di Indonesia, data dari Kemenristek Dikti memperlihatkan peningkatan jumlah mata kuliah yang ikut Blended Learning. Peningkatan ini tentunya juga mempengaruhi jumlah mahasiswa yang ikut serta di dalam kegiatan pembelajaran dengan menggunakan teknologi ini. Di samping itu juga disediakan mata kuliah Daring atau Online Course dan Pendidikan Profesi Guru yang tentunya juga akan mempengaruhi jumlah peserta yang mengikuti pembelajaran dengan teknologi ini [35]-[37].

Bila melihat tingginya penerimaan Generasi $Z$ terhadap pembelajaran ini, tentunya bisa dikaitkan dengan karakteristik Generasi $\mathrm{Z}$ sebagai peserta terbanyak dalam pembelajaran dengan menggunakan teknologi ini. Generasi $\mathrm{Z}$ memiliki orientasi yang bagus untuk pendidikan terutama pembelajaran seumur hidup, memiliki kemampuan dan pengetahuan yang banyak terkait teknologi karena integrasi mereka yang tinggi pada internet [4]. Namun demikian apakah ini merupakan kemauan para Generasi Z sendiri atau mereka hanya mengikuti pembelajaran ini karena diwajibkan dari mata kuliah tertentu yang mereka ikuti di kampus?

\subsection{Kemampuan Generasi $Z$ dalam Pembelajaran Mandiri}

Memang benar Generasi $Z$ tertarik mengikuti pembelajaran dengan menggunakan teknologi. Namun menurut Mc Connell (2018) di Cina partisipasi online Generasi Z ini rendah karena kurang inisiatif. Kemandirian mereka dalam pembelajaran e-learning mandiri sangat tergantung latar belakang yang mereka miliki, dan cenderung mengharapkan dosen menjelaskan secara lengkap pada mereka [24]. 
Kondisi ini kemungkinan karena Generasi Z memiliki karakter kurang memiliki komitmen, mudah puas secara instan, mencari kesenangan dan hidup untuk saat ini [13]. Generasi Z kurang mampu menvalidasi semua informasi yang ia peroleh [5]. Rentang perhatiannya singkat [6]. Ketika Generasi Z tertarik pada pembelajaran dengan menggunakan teknologi, meraka akan serius dalam menjalani proses ini, namun karena kecenderungan mereka mudah puas dan komitmen mereka rendah ditambah dengan rentang perhatian yang singkat akan membuat mereka hanya sesaat untuk benar-benar berkomitmen menjalaninya secara antusias dan serius. Selanjutnya mereka akan menjalaninya hanya sekedar mengikuti arahan dan tuntutan yang diberikan dosen atau penyelenggara pembelajaran. Bahkan kadang mereka menjadi lebih sibuk dengan hal-hal lain yang dianggap menarik, seperti chat melalui media sosial atau melihat informasiinformasi lain yang tidak terlalu terkait dengan konten pembelajaran. Ada kalanya mereka lebih sibuk mengumpulkan informasi tambahan dari sumber yang belum tentu dapat dipercaya karena mereka sendiri tidak memiliki kemampuan memvalidasi informasi yang masuk.

Kebosanan dan demotivasi akan lebih mudah terasa disaat system atau fasilitas dalam penggunaan pembelajaran baik e-learnig, termasuk mobile-learning ataupun digital learning mendukung jalannya pembelajaran. Bila sistem dan fasilitas tidak memadai maka Generasi $\mathrm{Z}$ yang terbiasa menggunakan teknologi informasi dan komunikasi ini akan cenderung bosan dan kehilangan semangat dalam menjalani proses pembelajaran. Ini terlihat dari faktor-faktor yang mempengaruhi penerimaan mahasiswa dalam menggunakan e-learning di Malaysia ataupun di Uni Emirat Arab [26], [29]. Hal sama tentunya juga dirasakan oleh Generasi $\mathrm{Z}$ di Indonesia ataupun tempat-tempat lain.

Di Indonesia karena pembelajaran menggunakan teknologi sangat difasilitasi oleh Pemerintah, tentunya proses pembelajarannya juga dipantau oleh Pemerintah. Hal ini akan menyebabkan Generasi Z sebagai peserta mau tidak mau akan mengikuti proses Blended Learning sesuai dengan standar yang ditetapkan. Tetapi masih perlu diteliti bagaimana inisiatif Generasi Z ketika menjalani kuliah Daring atas kemauan sendiri yang juga diadakan oleh Direktorat Jenderal Belmawa Kemenristek Dikti. Apalagi bila yang menjadi target adalah Generasi $\mathrm{Z}$ yang berada di pelosok-pelosok negeri yang kemungkinan jaringan internet pun masih kurang memadai.

\subsection{Pembelajaran dengan Teknologi untuk Meningkatkan Literasi Manusia pada Generasi $Z$ di Indonesia?}

Apakah pembelajaran dengan menggunakan teknologi benar-benar dapat meningkatkan literasi manusia, terutama untuk Generasi Z? Untuk menjawab pertanyaan ini dapat digunakan analisis SWOT seperti pada tabel 3.1.

Tabel 3.1

Analisis SWOT Pembelajaran dengan Teknologi untuk Meningkatkan Literasi Manusia pada Generasi Z di Indonesia

\begin{tabular}{|l|ll|}
\hline \multicolumn{1}{|c|}{ Kekuatan } & \multicolumn{1}{c|}{ Kelemahan } \\
\hline$\bullet$ & Pembelajaran dengan teknologi & Bagi sebagian Generasi Z di daerah- \\
didukung langsung oleh Pemerintah & daerah pedalaman mungkin kesulitan \\
dengan mengadakan pembelajaran & untuk menggunakan pembelajaran \\
Daring & $\begin{array}{l}\text { dengan menggunakan teknologi karena } \\
\text { tidak terbiasa menggunakannya }\end{array}$ \\
\hline
\end{tabular}


- Generasi Z sangat menyukai penggunaan teknologi dalam kehidupan sehari-harinya sehingga kemungkinan lebih menyukai pembelajaran dengan teknologi ini

- Tersedianya berbagai macam informasi untuk meningkatkan pengetahuan peserta pembelajaran
- Masih banyak kawasan atau Perguruan Tinggi yang memiliki fasilitas yang kurang memadai untuk penggunaan pembelajaran dengan teknologi ini seperti jaringan internet yang tidak lancar

- Sulit memberikan pembelajaran yang terkait dengan soft skills bila hanya mengandalkan e-learning (daring)

- Semakin sering menggunakan $e^{-}$ learning kemampuan komunikasi lisan Generasi Z semakin rendah

- Memperpanjang waktu paparan teknologi terhadap Generasi Z
- Menciptakan games online untuk simulasi pembelajaran seperti terkait pengambilan keputusan

- Membangun situs web pembelajaran untuk menunjang peningkatan literasi manusia yang disesuaikan dengan norma, budaya dan etika di Indonesia

Ancaman

- Bila tidak adanya pengaturan yang baik dalam pencarian informasi, Generasi Z semakin rentan memperoleh informasi yang isinya tidak dapat dipertanggungjawabkan dan dapat merusak etika dan moral mereka

- Karena informasi dari berbagai macam budaya yang mungkin bertolak belakang dengan budaya Indonesia dan ketimuran akan menyebabkan Generasi Z semakin tidak memahami budaya Negara sendiri

Sejauh ini materi-materi pembelajaran yang diberikan tentunya disesuaikan dengan kurikulum serta tujuan pembelajaran yang telah ditetapkan. Untuk peningkatan pengetahuan secara kognitif pembelajaran online sebenarnya hampir sama dengan pembelajaran face to face. Apalagi untuk pembelajaran blended, peningkatan pengetahuan untuk kognitifnya akan lebih terasa karena dirancang di bawah pengawasan instruktur atau dosen, berdasarkan standar dari Ristek Dikti dan interaksi antara mahasiswa dengan dosen dapat dilakukan baik secara online maupun offline. Dengan demikin untuk mata kuliah yang ikut pembelajaran daring ataupun blended terkait untuk pemahaman teknologi seharusnya dapat mencapai peningkatan literasi teknologi dan data. Peningkatan literasi teknologi dan data ini akan semakin terasa bila materi yang diberikan diiringi dengan praktek yang cukup.

Dengan karakter Generasi Z yang menggunakan teknologi informasi secara intuitif karena dari lahir terbiasa dengan teknologi [13] seharusnya peningkatan kemampuan literasi teknologi dan data menjadi lebih mudah bagi mereka. Namun bila mengingat bahwa Generasi Z lebih banyak menghabiskan waktunya untuk online untuk you tube ataupun media sosial seperti instagram dan snapchat [14], ada dugaan yang perlu dibuktikan bahwa mereka lebih banyak sebagai penikmat atau penonton saja, hanya segelintir yang memanfaatkan aplikasi-aplikasi tersebut untuk meningkatkan kemampuan 
dan kreativitas mereka. Ini juga didukung kebiasaan mereka cenderung kurang berpikir panjang dan pencari kesenangan [13].

Peningkatan literasi manusia untuk Generasi Z akan lebih sulit. Literasi manusia yang mencakup kemampuan komunikasi, kolaborasi, berpikir kritis, kreatif, dan inovatif akan lebih sulit bila hanya mengandalkan pembelajaran online saja. Literasi manusia ini sangat berkaitan dengan pengembangan karakter. Sampai saat ini pengembangan karakter melalui face to face-learning juga dinilai masih belum terlalu berhasil, apalagi hanya mengandalkan pembelajaran online saja. Kemampuan berinteraksi secara langsung yang kurang disukai oleh Generasi $\mathrm{Z}$ dibandingkan komunikasi melalui online akan membuat peningkatan literasi manusia semakin sulit tercapai.

Pada kenyatannya Generasi Z masih membutuhkan bimbingan dari dosen dalam pembelajaran [14]. Ini terutama disebabkan karena Generasi Z cenderung kurang berpikir panjang dan mencari kesenangan [13]. Secara umum pembelajaran dengan teknologi sejauh ini lebih banyak bermanfaat untuk peningkatan pengetahuan atau kognitif, untuk itulah praktek di lapangan di bawah bimbingan langsung dari dosen baik secara online terutama secara offline menjadi suatu keharusan bagi Generasi Z.

Terlalu banyak mengandalkan pembelajaran dengan teknologi pada Generasi Z hanya akan membuat tingkat ketergantungan mereka pada teknologi semakin tinggi. Sebaliknya mereka akan semakin sulit untuk berinteraksi dan bersosialisasi secara langsung. Padahal kemampuan literasi manusia sangat membutuhkan pengalaman kepemimpinan dan pemecahan masalah yang kemungkinan akan lebih mudah di dapat melalui interaksi langsung dan keikutsertaan dalam organisasi.

Saat ini dengan kemampuan validasi informasi yang rendah, namun memiliki beragam data dan informasi akan membuat mereka lebih sulit menganalisis suatu masalah. Ditambah dengan semakin rendahnya nilai-nilai tradisional mereka, menjadi tugas besar bagi generasi sebelumnya untuk membantu pengembangan karakter Generasi Z. Meskipun kepedulian universal yang dimiliki Generasi $Z$ perlu kita hargai, namun nilai-nilai budaya yang cenderung dianggap Generasi $Z$ kuno tetap perlu ditegakkan. Nilai-nilai ini merupakan identitas suatu bangsa. Seperti yang terjadi di kawasan Timur Tengah yang mengkhawatirkan bercampur baurnya lawan jenis melalui komunikasi online, perlu dipikirkan cara terbaik dalam mengatur penerapan pembelajaran menggunakan teknologi agar dapat meminimalisir kemungkinan percampuran tersebut.

Penggunaan e-learning tetap dibutuhkan dalam pembelajaran terutama untuk memberikan informasi apa yang terjadi di negara sendiri ataupun di dunia, yang dapat memperlihatkan masalah-masalah dalam kehidupan manusia, masalah akibat kesalahan dalam komunikasi atau kesalahan dalam pengambilan keputusan yang dapat menimbulkan peperangan atau bencana. Namun, untuk mengasah kemampuan komunikasi, leadership dan juga pengambilan keputusan dibutuhkan praktek di dunia nyata daripada dilakukan di dunia maya.

\section{Kesimpulan}

Generasi $\mathrm{Z}$ memiliki karakteristik tertentu yang berbeda dengan generasi-generasi lainnya. Terkait pembelajaran yang menggunakan teknologi, meskipun mereka pada umumnya menerima dan cukup antusias namun masih sangat dibutuhkan interaksi yang intensif antara Generasi $Z$ dengan dosen-dosennya. Hal ini disebabkan karena karakteristik Generasi $\mathrm{Z}$ yang cenderung ingin instan, hidup untuk saat ini, rentang perhatian yang pendek dan kemampuan validasi informasi yang rendah. 
Untuk peningkatan literasi manusia, Generasi $\mathrm{Z}$ masih sangat membutuhkan banyak praktek langsung di dunia nyata, ditambah penggunaan teknologi untuk mencari informasi aktual tentang yang terjadi di negara sendiri ataupun dunia luar.

Dibutuhkan penelitian lanjutan terkait bagaimana model pembelajaran penggunaan teknologi yang lebih tepat untuk peningkatan literasi manusia untuk Generasi Z. Hal ini disebabkan penggunaan teknologi yang terlalu sering justru akan membuat Generasi $\mathrm{Z}$ kehilangan kemampuan dalam berinteraksi dan bersosialisasi secara langsung.

\section{Daftar Pustaka}

[1] A. Turner, "Generation Z: Technology and Social Interest," J. Individ. Psychol., vol. 71, no. 2, pp. 103-113, 2015, doi: 10.1353/jip.2015.0021.

[2] S. B. Berkup, "Working With Generations X And Y In Generation Z Period: Management Of Different Generations In Business Life," Mediterr. J. Soc. Sci., Aug. 2014, doi: 10.5901/mjss.2014.v5n19p218.

[3] D. M. Kennedy and B. Fox, "Digital natives': An Asian perspective for using learning technologies," Int. J. Educ. Dev. Using Inf. Commun. Technol. IJEDICT, vol. 9, no. 1, pp. 6479, 2013.

[4] A. Pérez-Escoda, A. Castro-Zubizarreta, and M. Fandos-Igado, "Digital Skills in the Z Generation: Key Questions for a Curricular Introduction in Primary School," Comunicar, vol. 24, no. 49, pp. 71-79, 2016, doi: 10.3916/C49-2016-07.

[5] B. Shatto and K. Erwin, "Moving on From Millennials: Preparing for Generation Z," $J$. Contin. Educ. Nurs., vol. 47, pp. 253-254, Jun. 2016, doi: 10.3928/00220124-20160518-05.

[6] J. B. Mosca, K. P. Curtis, and P. G. Savoth, "New Approaches to Learning for Generation Z," J. Bus. Divers., vol. 19, no. 3, p. 10, 2019.

[7] A. A. Hussin, "Education 4.0 Made Simple: Ideas For Teaching," Int. J. Educ. Lit. Stud., vol. 6, no. 3, pp. 92-98, Jul. 2018, doi: 10.7575/aiac.ijels.v.6n.3p.92.

[8] K.-W. Lai and K.-S. Hong, "Technology use and learning characteristics of students in higher education: Do generational differences exist?," Br. J. Educ. Technol., vol. 46, no. 4, pp. 725738, 2015, doi: 10.1111/bjet.12161.

[9] G. Molnár, "Teaching and learning in modern digital environment," in 2015 IEEE 13th International Symposium on Applied Machine Intelligence and Informatics (SAMI), 2015, pp. 213-217, doi: 10.1109/SAMI.2015.7061878.

[10] "Menristekdikti Luncurkan E-Learning/ Hybrid Learning, Strategi Pendidikan Tinggi untuk Kaum Milenial," Spada Indonesia, 2018. [Online]. Available: http://spada.ristekdikti.go.id/berita/menristekdikti-luncurkan-e-learning-hybrid-learningstrategi-pendidikan-tinggi-untuk-kaum-milenial/. [Accessed: 13-Dec-2019].

[11] Belmawa, "Era Revolusi Industri 4.0: Perlu Persiapkan Literasi Data, Teknologi dan Sumber Daya Manusia - Direktorat Jenderal Pembelajaran dan Kemahasiswaan.” [Online]. Available: https://belmawa.ristekdikti.go.id/era-revolusi-industri-4-0-perlu-persiapkan-literasi-datateknologi-dan-sumber-daya-manusia/. [Accessed: 29-Dec-2019].

[12] R. Zemke, C. Raines, and B. Filipczak, Generations at Work: Managing the Clash of Veterans, Boomers, Xers, and Nexters in Your Workplace, First. New York, NY, USA: Amacom, 1999.

[13] A. Bencsik and T. Juhász, "Y and Z Generations at Workplaces," J. Compet., vol. 8, no. 3, pp. 90-106, Sep. 2016, doi: 10.7441/joc.2016.03.06.

[14] The Harris Poll, "Beyond Millennials: The Next Generation of Learners," Pearson Learning News, 08-Aug-2018. [Online]. Available: https://www.pearsonlearned.com/beyondmillennials-the-next-generation-of-learners/. [Accessed: 23-Dec-2019]. 
[15] V. J. Rideout, U. G. Foehr, and D. F. Roberts, Generation M[superscript 2]: Media in the Lives of 8-to 18-Year-Olds. Henry J, 2010.

[16] J. E. Ormrod, Human Learning, Global Edition, 7th ed. Pearson, New York, 2016.

[17] W. I. O'Byrne and K. E. Pytash, "Hybrid and Blended Learning," J. Adolesc. Adult Lit., vol. 59, no. 2, pp. 137-140, 2015, doi: 10.1002/jaal.463.

[18] U. A. Chaeruman, "Pedati -Model Desain Sistem Pembelajaran Blended. Panduan Merancang Mata Kuliah Daring SPADA Indonesia." Direktorat Pembelajaran dan Kemahasiswaan Kemenristek Dikti, 2017.

[19] G. S. and D. G. and S. Dawson, "Preparing for the Digital University: a review of the history and current state of distance, blended, and online learning," 2015.

[20] J. L. Moore, C. D. Deane, and K. Galyen, "e-Learning, online learning, and distance learning environments: Are they the same? - ScienceDirect," Internet High. Educ., vol. 14, 2011.

[21] D. Tavangarian, M. E. Leypold, K. Nölting, M. Röser, and D. Voigt, "Is e-Learning the Solution for Individual Learning?," Electron. J. E-Learn., vol. 2, no. 2, pp. 273-280, 2004.

[22] C. Lewis, "Lesson Study: A handbook of teacher-led instructional change," Jan. 2002.

[23] L. C. Medina, "Blended learning: Deficits and prospects in higher education," Australas. J. Educ. Technol., vol. 34, no. 1, Mar. 2018, doi: 10.14742/ajet.3100.

[24] D. McConnell, "E-learning in Chinese higher education: the view from inside," High. Educ., vol. 75, no. 6, pp. 1031-1045, Jun. 2018, doi: 10.1007/s10734-017-0183-4.

[25] W. M. Al-Rahmi et al., "Use of E-Learning by University Students in Malaysian Higher Educational Institutions: A Case in Universiti Teknologi Malaysia," IEEE Access, vol. 6, pp. 14268-14276, 2018, doi: 10.1109/ACCESS.2018.2802325.

[26] M. S. Taat and A. Francis, "Factors Influencing the Students' Acceptance of E-Learning at Teacher Education Institute: An Exploratory Study in Malaysia," Int. J. High. Educ., vol. 9, 2020.

[27] A. A. Mirza and M. Al-Abdulkareem, "Models of e-learning adopted in the Middle East," Appl. Comput. Inform., vol. 9, no. 2, pp. 83-93, Jul. 2011, doi: 10.1016/j.aci.2011.05.001.

[28] A. Al-Hunaiyyan, R. A. Alhajri, and S. Al-Sharhan, "Perceptions and challenges of mobile learning in Kuwait," J. King Saud Univ. - Comput. Inf. Sci., vol. 30, no. 2, pp. 279-289, Apr. 2018, doi: 10.1016/j.jksuci.2016.12.001.

[29] S. A. Salloum, M. Al-Emran, K. Shaalan, and A. Tarhini, "Factors affecting the E-learning acceptance: A case study from UAE," Educ. Inf. Technol., vol. 24, no. 1, pp. 509-530, Jan. 2019, doi: 10.1007/s10639-018-9786-3.

[30] A. S. M.Pd, "Pemerataan Pendidikan Melalui Sistem Pembelajaran Daring," Spada Indonesia. [Online]. Available: http://spada.ristekdikti.go.id/berita/pemerataan-pendidikanmelalui-sistem-pembelajaran-daring/. [Accessed: 13-Dec-2019].

[31] "Belmawa Dukung Penyelenggaraan Pendidikan berbasis IT," Spada Indonesia, 01-Mar2019. [Online]. Available: http://spada.ristekdikti.go.id/berita/belmawa-dukungpenyelenggaraan-pendidikan-berbasis-it/. [Accessed: 13-Dec-2019].

[32] "Konten Pembelajaran Jarak Jauh Penting Disiapkan untuk Generasi Milenial," Spada Indonesia, 30-Aug-2019. [Online]. Available: http://spada.ristekdikti.go.id/berita/kontenpembelajaran-jarak-jauh-penting-disiapkan-untuk-generasi-milenial/. [Accessed: 13-Dec2019].

[33] "Sistem Pembelajaran Daring (SPADA)," Direktorat Jenderal Pembelajaran dan Kemahasiswaan. [Online]. Available: https://belmawa-dev.ristekdikti.go.id/sistempembelajaran-daring/. [Accessed: 24-Dec-2019].

[34] A. McFarlane, A. Bradburn, and A. McMahon, "E-Learning for Leadership: Emerging indicators of effective practice," Natl. Coll. Sch. Leadersh., 2003.

[35] "Katalog Mata Kuliah Daring," Spada Indonesia. [Online]. Available: http://spada.ristekdikti.go.id/pages/kuliah-daring/. [Accessed: 29-Dec-2019]. 
[36] "Katalog Mata Kuliah Hybrid/Blended." [Online]. Available: https://spada.ristekdikti.go.id/pages/kuliah-terbuka. [Accessed: 29-Dec-2019].

[37] "Modul PPG Dalam Jabatan," Spada Indonesia. [Online]. Available: http://spada.ristekdikti.go.id/pages/ppg/. [Accessed: 29-Dec-2019]. 